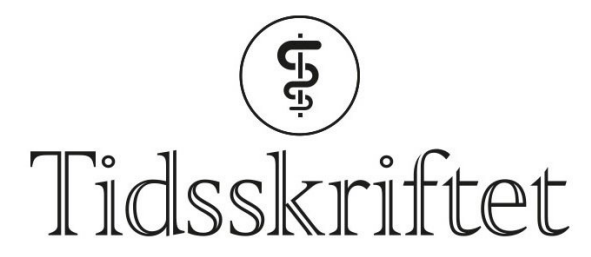

DEN NORSKE LEGEFORENING

\title{
Mye feilbehandling med antibiotika
}

FRA ANDRE TIDSSKRIFTER

KETIL SLAGSTAD

Tidsskriftet

Svært mange antibiotikaforskrivninger i en stor studie i USA manglet adekvat indikasjon.

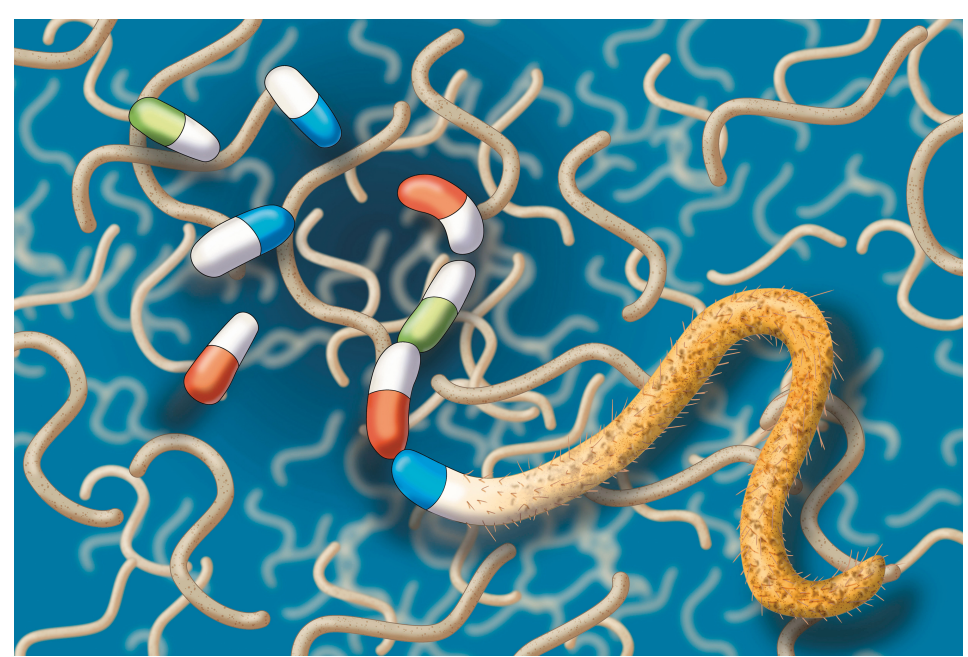

Illustrasjon: Science History Images / Alamy Stock Photo

Overbehandling og feilbehandling med antibiotika er en viktig årsak til økt antibiotikaresistens. Dette gjelder bl.a. forskrivning av antibiotika mot virale øvre luftveisinfeksjoner.

En ny studie publisert i tidsskriftet The BMJ omfattet legeopplysninger for over 28 ooo konsultasjoner i 2015 blant amerikanske leger der antibiotika ble forskrevet (1). Utvalget var representativt for over 990 millioner legebes $ø$ k. 13,2 \% av besøkene førte til forskrivning av et antibiotikum. I $57 \%$ av disse bes $\varnothing$ kene ble det dokumentert en diagnosekode tilsvarende bakteriell infeksjon, i $25 \%$ av tilfellene var indikasjonen feil og i $18 \%$ manglet det informasjon til å ta stilling til indikasjon. Dette tilsvarte rundt 24 millioner antibiotikaforskrivninger uten indikasjon. Det var flere menn enn kvinner som fikk forskrevet antibiotika uten indikasjon, og sannsynligheten for å få forskrevet antibiotika på feil indikasjon var signifikant lavere hos allmennlege enn hos andre spesialister (12\% vs. $24 \%)$ og hos fastlege vs. andre leger (14\% vs. $23 \%$ ).

- Denne studien viser utfordringer knyttet til koding av akutte infeksjoner i primærhelsetjenesten, sier Guro Haugen Fossum, som er postdoktor ved Avdeling for allmennmedisin ved Universitetet i Oslo. - Dersom man skal bruke diagnosekoder til å monitorere korrekt antibiotikabruk, bør man vite hvordan leger koder infeksjoner. Vi vet at norske leger bruker diagnosekodene i ICPC-2 forskjellig, sier hun. Som eksempel nevner 
hun diagnosen bronkitt, hvor antibiotika egentlig ikke er indisert, men der legen kan tenke at det er en pneumoni og likevel lar diagnosekoden bli stående.

- Ved Antibiotikasenteret for primærmedisin har vi lenge ønsket at legene skal kunne påføre en indikasjonskode direkte på antibiotikaresepten og at diagnosekoden blir registrert i Reseptregisteret. Bare slik kan man med sikkerhet vite hvilken sykdom legen $\emptyset$ nsker å behandle, sier Fossum.

LITTERATUR:

1. Ray MJ, Tallman GB, Bearden DT et al. Antibiotic prescribing without documented indication in ambulatory care clinics: national cross sectional study. BM] 2019;367: 16461. [PubMed][CrossRef]

Publisert: 22. mars 2020. Tidsskr Nor Legeforen. DOI: 10.4045/tidsskr.20.00o9

(C) Tidsskrift for Den norske legeforening 2020. Lastet ned fra tidsskriftet.no 